\title{
EFFICIENT PLANT REGENERATION VIA INDIRECT ORGANOGENESIS IN CARNATION (DIANTHUS CARYOPHYLLUS SEMPERFLORENS FLORE PLENO) CULTIVARS
}

\author{
Hamid Reza SABAGHI ${ }^{1}$, Gholamreza SHARIFI-SIRCHI ${ }^{2 *}$, Pejman AZADI ${ }^{3 * \mathbb{D} \text {, }}$ \\ Mohammad Hossein AZIMI ${ }^{4}$ \\ ${ }^{1}$ Horticultural Science Department, Agriculture and Natural Resources College, \\ University of Hormozgan, Bandar Abbas, Iran \\ ${ }^{2}$ Department of Biotechnology Engineering, Faculty of Agriculture \\ Shahid Bahonar University of Kerman, Kerman, Iran \\ ${ }^{3}$ Agricultural Biotechnology Research Institute, Agricultural Research, \\ Education and Extension Organization (AREEO), Karaj, Iran \\ ${ }^{4}$ Department of Biotechnology, Ornamental Plants Research Institute, \\ Horticultural Science Research Institute, Mahallat, Iran \\ Received: August 2021; Accepted: November 2021
}

\begin{abstract}
Callus induction and plant regeneration are important steps of in vitro plant breeding of ornamental plants. In this study, the effects of different combinations of plant growth regulators (PGRs), promoters, and minerals on callus induction and plant regeneration in different carnation cultivars were studied in a completely randomized design with three replications. For callus induction, 16 different combinations of 2,4-dichlorophenoxyacetic acid (2,4-D), 6-benzylaminopurine (BA), 1-naphthaleneacetic acid (NAA), and casein hydrolysate $(\mathrm{CH})$ were studied using in vitro leaf explants. The Murashige and Skoog (MS) medium supplemented with $0.2 \mathrm{mg} \cdot \mathrm{dm}^{-3}$ of 2,4-D and $200 \mathrm{mg} \cdot \mathrm{dm}^{-3}$ of $\mathrm{CH}$ showed the highest frequency of callus induction. Among the cultivars, 'Noblesse' showed the highest rate of callus induction (91.67\%). Regarding regeneration, $\mathrm{BA}, \mathrm{NAA}$, silver nitrate $\left(\mathrm{AgNO}_{3}\right)$, and adenine hemisulfate (As) were used in ten different combinations. The 'Cameron', 'Tabasco', and 'Noblesse' cultivars with $95.24 \%$ regeneration percentage showed the highest rate of plant regeneration. Generally, in most cultivars, the highest regeneration rate and shoot number per explant were found in the MS medium supplemented with $3 \mathrm{mg} \cdot \mathrm{dm}^{-3}$ of BA, $0.6 \mathrm{mg} \cdot \mathrm{dm}^{-3}$ of NAA, $5 \mathrm{mg} \cdot \mathrm{dm}^{-3}$ of $\mathrm{AgNO}_{3}$, and $40 \mathrm{mg} \cdot \mathrm{dm}^{-3}$ of As. According to the results, the highest regeneration frequency was obtained when $40 \mathrm{mg} \cdot \mathrm{dm}^{-3}$ of As was added to the medium. Finally, the flow cytometry analysis indicated that there were no significant differences between in vitro regenerated and control plants in terms of DNA ratios.
\end{abstract}

Key words: silver nitrate, adenine hemisulfate, callus induction, shoot regeneration

\section{INTRODUCTION}

Carnation (Dianthus caryophyllus L.) is a member of the large Caryophyllaceae family, with 80 genera and about 2000 species, which are either annual or perennial and grow mostly in the northern hemisphere (Maurya et al. 2020). The standard carnation species $(2 \mathrm{n}=30)$ with a large flower size is the most important of these, used as a cut flower around the world. Due to its excellent storage quality, a wide range of forms and colors, the ability to withstand long-distance transportation, and its remarkable ability to rehydrate after continuous shipping, this plant has special value in the flower industry (Iantcheva 2016). 
There are several obstacles for carnation hybridization breeding, including lack of viable and sufficient pollen, cross-incompatibility, chromosomal aberrations, lack of viable gametes, post-zygotic barriers at an immature stage, and embryo without endosperm (Dyaberi et al. 2015). Therefore, in vitro breeding methods are widely used to breed this species (Azadi et al. 2016). Direct or indirect plant regeneration is a major prerequisite for genetic transformation and in vitro mutation breeding techniques (Casas et al. 2010; Ntui et al. 2010). Various plant growth regulators (PGRs) have been used in earlier studies, and in most cases, a high concentration of cytokinin, including TDZ was necessary for shoot regeneration in different carnation cultivars (Thakur \& Kanwar 2018; Thu et al. 2020; Maurya et al. 2021). In the in vitro regeneration other additions can play a useful role. Addition of silver nitrate $\left(\mathrm{AgNO}_{3}\right)$ to the regeneration media was successful in direct plant regeneration from cotyledon explants in Cosmos bipinnatus (Jaberi et al. 2018). Also casein hydrolysate $(\mathrm{CH})$ and adenine hemisulfate (As) were effective in the regeneration of different species (Khaleda \& Al-Forkan 2006; Gatica Arias et al. 2010; Arora et al. 2011; Pandey \& Tamta 2014; Cardoso 2019; Al Ramadan et al. 2021; Lakshmi et al. 2021; Maurya et al. 2021).

In vitro culture techniques are useful in overcoming hybridization barriers in carnation, in in vitro mutagenesis and genetic transformation. In this study, an efficient protocol for high-frequency callus induction from leaf explants and plant regeneration via indirect shoot organogenesis was established using different PGRs, $\mathrm{AgNO}_{3}$, As, and $\mathrm{CH}$, in nine standard carnation cultivars. The objective of this study is to develop a plant regeneration protocol for different cultivars of carnation via callus induction, using in vitro leaf explants.

\section{MATERIALS AND METHODS}

\section{Plant materials}

Nine standard carnation cultivars - 'Cameron', 'Eskimo', 'Grand Slam', 'Liberty', 'Mariposa', 'Noblesse', 'Tabasco', 'Tabor', and 'White Liberty'-were studied.
The in vitro leaf explants obtained from axillary buds were excised into $0.5-0.7 \mathrm{~cm}$ pieces, followed by incubation with the axial side down on the Murashige and Skoog (1962) (MS) basal medium. In all experiments, culture conditions included a temperature of $25 \pm 2{ }^{\circ} \mathrm{C}$ under a PPFD of $80 \mu \mathrm{mol} \cdot \mathrm{m}^{-2} \cdot \mathrm{s}^{-1}$ using fluorescent light with a $16-\mathrm{h}$ photoperiod.

\section{Callus induction}

The leaf segments were incubated on the MS media containing $30 \mathrm{~g} \cdot \mathrm{dm}^{-3}$ of sucrose, solidified with $0.7 \%$ (w/v) Plant agar (Duchefa Biochemie) at $\mathrm{pH} 5.8$, before autoclaving and supplemented with different concentration of 2,4-dichlorophenoxyacetic acid (2,4-D) $\left(0,0.2,0.5\right.$, and $\left.1 \mathrm{mg} \cdot \mathrm{dm}^{-3}\right), 1$-naphthaleneacetic acid (NAA) $\left(0\right.$ and $\left.0.5 \mathrm{mg} \cdot \mathrm{dm}^{-3}\right), 6$-benzylaminopurine (BA) $\left(0,0.2\right.$, and $\left.0.5 \mathrm{mg} \cdot \mathrm{dm}^{-3}\right)$, and $\mathrm{CH}(0$ and $200 \mathrm{mg} \cdot \mathrm{dm}^{-3}$ ) in 16 different combinations (Table 1 ). For callus induction leaf explants were cultured in 80mm Petri dishes containing $25 \mathrm{ml}$ of fresh MS medium.

\section{Indirect organogenesis}

For shoot regeneration, three-week-old calluses were transferred to the MS media supplemented with BA $\left(0,2,3\right.$, and $\left.5 \mathrm{mg} \cdot \mathrm{dm}^{-3}\right)$, NAA $(0,0.2$, and $\left.0.6 \mathrm{mg} \cdot \mathrm{dm}^{-3}\right)$, As $\left(0,20,40\right.$, and $\left.80 \mathrm{mg} \cdot \mathrm{dm}^{-3}\right)$, and $\mathrm{AgNO}_{3}\left(0\right.$ and $\left.5 \mathrm{mg} \cdot \mathrm{dm}^{-3}\right)$ in 10 different combinations, in culture jars $(10 \times 6 \mathrm{~cm}) . \mathrm{AgNO}_{3}$ was filtersterilized through a $0.24-\mu \mathrm{m}$ Millipore membrane and added to the autoclaved culture media. The other compounds were added prior to the autoclaving at $121^{\circ} \mathrm{C}$ for $15 \mathrm{~min}$.

\section{Overcoming hyperhydricity and shoot proliferation}

To eliminate hyperhydricity of regenerated shoots caused by high concentrations of cytokines, hyperhydric shoots were transferred to a modified MS recovery medium containing $0.275 \mathrm{~g} \cdot \mathrm{L}^{-1}$ of $\mathrm{NH}_{4} \mathrm{NO}_{3}$ with $0.5 \mathrm{mg} \cdot \mathrm{dm}^{-3}$ gibberellic acid $\left(\mathrm{GA}_{3}\right)$, $0.3 \mathrm{mg} \cdot \mathrm{dm}^{-3} \mathrm{BA}$, and $0.1 \mathrm{mg} \cdot \mathrm{dm}^{-3}$ NAA based on a pilot experiment (data not shown) for about two weeks. $\mathrm{GA}_{3}$ was filter-sterilized through a $0.24-\mu \mathrm{m}$ filter and added to the media after autoclaving.

\section{Shoot elongation, root formation, and acclimati-} zation

The regenerated shoots were cut off from the base and transferred for elongation to an agar-solidified 
MS elongation medium supplemented with $1 \mathrm{mg} \cdot \mathrm{dm}^{-3}$ of kinetin (KIN) and $0.1 \mathrm{mg} \cdot \mathrm{dm}^{-3}$ of NAA for three weeks. For root induction, the shoots with 4-7 leaves of $2-3 \mathrm{~cm}$ long were transferred to the $1 / 2$ MS medium (rooting medium) supplemented with $0.26 \mathrm{mg} \cdot \mathrm{dm}^{-3}$ of indole-3-butyric acid (IBA). After 14 days, root formation was observed (Figure 1G-I). The rooted plantlets with 58 leaves and a height of 3-4 $\mathrm{cm}$ were removed from the jars, and the agar was washed away gently from the roots with tap water. The plantlets were transplanted to plastic trays $(50 \times 40 \times 10 \mathrm{~cm})$ containing perlite, coco peat, and peat moss (1:1:1, $\mathrm{v} / \mathrm{v})$. They were then kept in a greenhouse under controlled conditions (a temperature of $25 \pm 2{ }^{\circ} \mathrm{C}$ under a PPFD of $100-110 \mu \mathrm{mol} \cdot \mathrm{m}^{-2} \cdot \mathrm{s}^{-1}$ and a relative humidity of $90 \%$ ) for acclimatization.

\section{Flow cytometry analysis}

The leaves of in vitro-regenerated plants and donor plants were finely chopped in $500 \mu \mathrm{l}$ of ice-cold nuclei extraction buffer (PVP: $10 \mathrm{mg}$, DNA-extraction buffer: $1 \mathrm{cc}$, RNase: $15 \mu \mathrm{l}$, and PI: $30 \mu \mathrm{l})$. Then, $2 \mathrm{ml}$ of nuclei staining solution (CyStain ${ }^{\circledR}$ PI Absolate P) was added to the crude mixture. To eliminate cell debris, the suspension was filtered with a $50-\mu \mathrm{m}$ filter, and the nuclei were collected into pre-chilled tubes. The ploidy level of the samples was analyzed by a flow cytometer (BD FACS Calibur, Biosciences, USA) using a 488-nm argon laser to excite the PI fluorochrome and an FL-2 detector with a 585/42 bandpass filter. Samples were run on low pressure, and 104 nuclei were counted within the double gate (Nalousi et al. 2019).

\section{Data collection and statistical analyses}

Each treatment contained 12 explants cultured in 80-mm Petri dishes with three replications. Different callus induction and plant regeneration parameters were collected, and the significant differences in means were statistically analyzed by one-way analysis of variance (one-way ANOVA). For nonnormal distribution data, logarithmic transformation was performed prior to further analysis. Values represent means \pm SD and different letters show a significant difference $(\mathrm{p}<0.05)$ based on Duncan's multiple range test (DMRT).

\section{RESULTS}

\section{Callus induction}

Significant differences were observed in callus formation depending on different combinations or concentrations of PGRs and genotype (Tables $1 \& 2$ ). The highest callus induction frequency was observed in the 'Noblesse' cultivar with $91.67 \%$ and the 'White Liberty' cultivar with $90.33 \%$. The results indicated that in treatments with a high callus growth rate, callus induction frequency significantly decreased. In this regard, 'Noblesse' and 'White Liberty' cultivars with the highest callus frequency percentage showed a slow growth rate (Table 2). And vice versa, in cultivars with a high callus growth rate (earlier callus induction), such as 'Cameron' and 'Eskimo', a lower callus induction frequency was observed. The MS medium supplemented with $0.2 \mathrm{mg} \cdot \mathrm{dm}^{-3}$ of $2,4-\mathrm{D}$ and $200 \mathrm{mg} \cdot \mathrm{dm}^{-3}$ of $\mathrm{CH}$ showed the highest quality of organogenic calli (the calli with the highest rate of plant regeneration with a green-yellow color and a semi-compact characteristic) among the cultivars (Figure 1A, B).

\section{Plant regeneration}

After four weeks, some green spots were observed on the surface of the calli (Figure 1C). After eight weeks, shoot regeneration was observed. Addition of As to the media significantly increased the percentage of shoot induction and the shoot number in all tested cultivars. While, in the MS medium supplemented with $3 \mathrm{mg} \cdot \mathrm{dm}^{-3}$ of BA, $0.6 \mathrm{mg} \cdot \mathrm{dm}^{-3}$ of $\mathrm{NAA}$, and $5 \mathrm{mg} \cdot \mathrm{dm}^{-3}$ of $\mathrm{AgNO}_{3}$ without As, the mean shoot regeneration rate was $53.96 \%$ among the cultivars. Adding $40 \mathrm{mg} \cdot \mathrm{dm}^{-3}$ of As significantly increased the regeneration rate to $78.83 \%$ (Table 3). The highest rate of regeneration was observed in 'Noblesse', 'Cameron', and 'Tabasco' cultivars with an average regeneration rate of $95.24 \%$. The 'Cameron' cultivar with 28.3 shoots per explant showed the highest number of shoots in each explant. In high concentrations of BA $\left(>3 \mathrm{mg} \cdot \mathrm{dm}^{-3}\right)$ and As $\left(>40 \mathrm{mg} \cdot \mathrm{dm}^{-3}\right)$, the rate of regeneration and the number of shoots decreased. In the MS medium supplemented with $3 \mathrm{mg} \cdot \mathrm{dm}^{-3}$ of BA, $0.6 \mathrm{mg} \cdot \mathrm{dm}^{-3}$ of NAA, $5 \mathrm{mg} \cdot \mathrm{dm}^{-3}$ of $\mathrm{AgNO}_{3}$, and $40 \mathrm{mg} \cdot \mathrm{dm}^{-3}$ of As, the highest rate of regeneration was observed in all the cultivars (Table 4). 


\section{Recovery of hyperhydricity, shoot elongation, rooting, and acclimatization}

In the majority of regenerated shoots, hyperhydricity was observed (Figure 1E). Such shoots were recovered from hyperhydricity on the recovery medium after two to three weeks (Figure 1F). Subsequently, the recovered plantlets were transferred to the MS elongation medium on which the shoots of all cultivars increased by approximately $2-3 \mathrm{~cm}$ after three weeks (Figure 1G).
All shoots were rooted after two weeks when transferred to the rooting medium (Figure $1 \mathrm{H}$ ). More than $80 \%$ of the plantlets survived transfer to greenhouse condition and acclimatized successfully (Figure 1I-K).

\section{Genetic stability assessment}

The genetic stability assessment using the flow cytometry analysis did not detect significant differences between in vitro-regenerated and control plants in terms of DNA ratios (Figure 2).

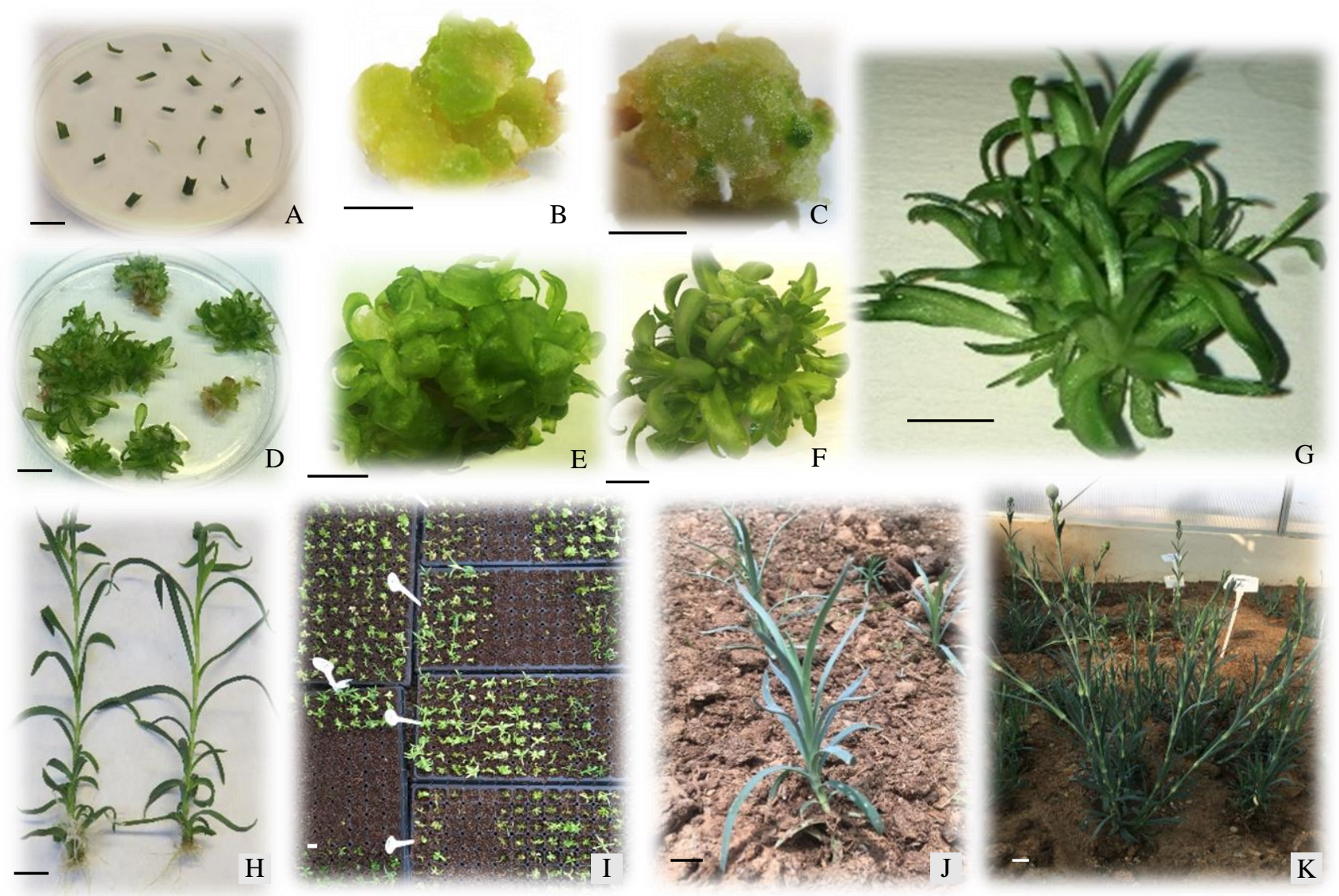

Figure 1. Different stages of organogenesis from leaf explants in carnation cultivars: A, B - explant type and callus induction after 21 days; $\mathrm{C}$ - green spots on the surface of the callus 25 days after sub-culture on the regeneration medium; D - efficient shoot induction on the MS medium supplemented with $3 \mathrm{mg} \cdot \mathrm{dm}^{-3}$ of BA, $0.6 \mathrm{mg} \cdot \mathrm{dm}^{-3}$ of NAA, $5 \mathrm{mg} \cdot \mathrm{dm}^{-3}$ of $\mathrm{AgNO}_{3}$, and $40 \mathrm{mg} \cdot \mathrm{dm}^{-3}$ of As two months after incubation; E - hyperhydric shoots regenerated in most explants; F - recovery from hyperhydricity on the modified MS $\left(0.275 \mathrm{mg} \cdot \mathrm{dm}^{-3}\right.$ of $\left.\mathrm{NH}_{4} \mathrm{NO}_{3}\right)$ containing $0.5 \mathrm{mg} \cdot \mathrm{dm}^{-3} \mathrm{of}$ $\mathrm{GA}_{3}, 0.3 \mathrm{mg} \cdot \mathrm{dm}^{-3}$ of BA, and $0.1 \mathrm{mg} \cdot \mathrm{dm}^{-3}$ of NAA after $2-3$ weeks; $\mathrm{G}$ - shoot elongation on the MS medium with $1 \mathrm{mg} \cdot \mathrm{dm}^{-3}$ of KIN and $0.1 \mathrm{mg} \cdot \mathrm{dm}^{-3}$ of NAA; $\mathrm{H}$ - rooting on the $1 / 2 \mathrm{MS}$ macro- and full micronutrients and $1.5 \mathrm{mg} \cdot \mathrm{dm}^{-3}$ of IBA; I - the acclimatization of plantlets in the greenhouse with controlled climate system and high relative humidity; $\mathrm{J}, \mathrm{K}$ - acclimatized plantlets transferred to the soil in the greenhouse (scale bars $=1 \mathrm{~cm}$ ) 

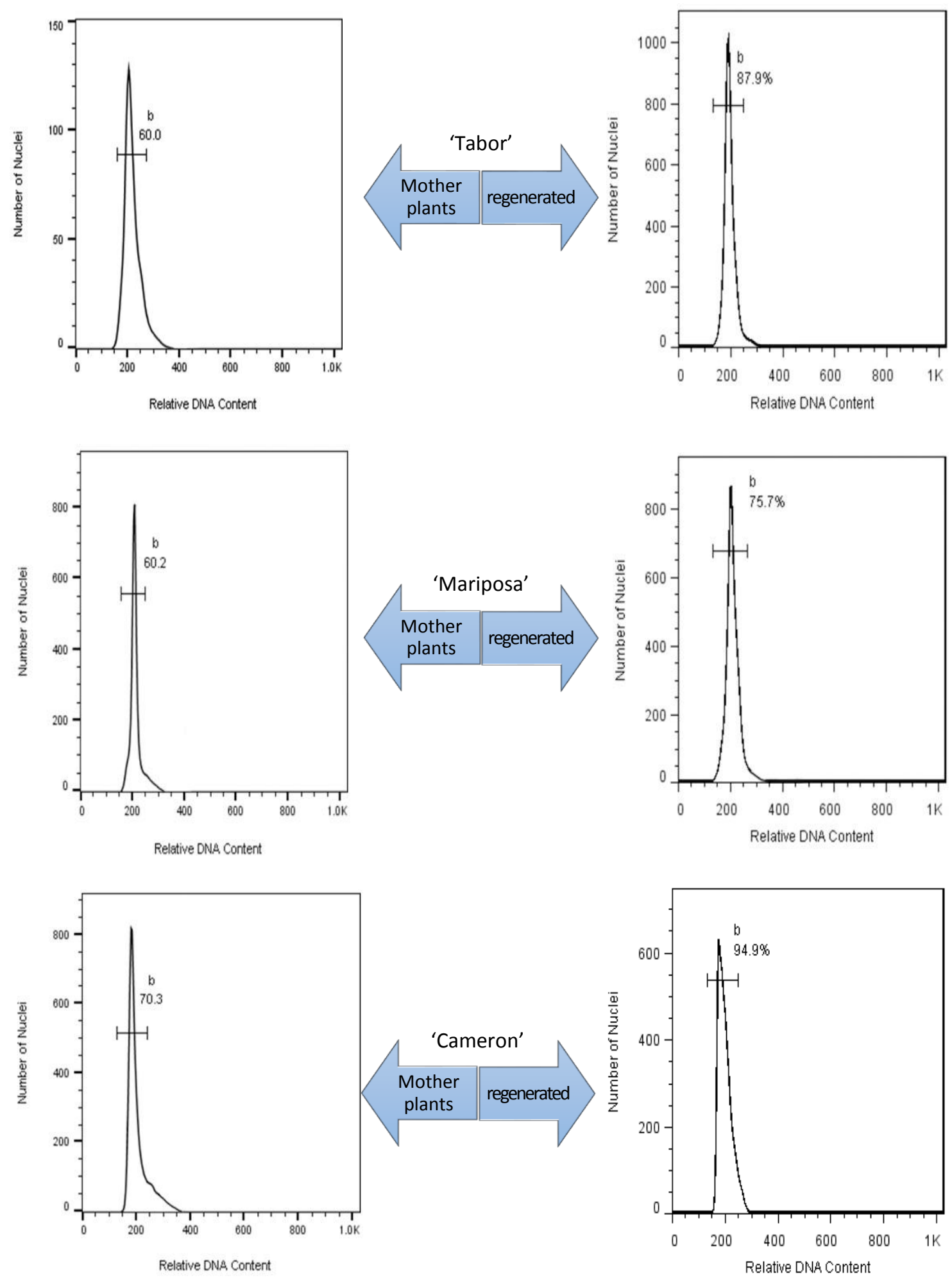

Figure 2. Ploidy level of the regenerated (right) and mother plants (left) of carnation cultivars through flow cytometry analysis. DNA content histogram in 'Tabor', 'Mariposa', and 'Cameron' cultivars showed no significant differences. The nuclei were isolated from the leaves of the mother and regenerated plants 
Table 1. Different PGR treatments used for callus induction from leaf segments of carnation

\begin{tabular}{|c|c|c|c|c|c|c|c|c|c|c|c|c|c|c|c|c|}
\hline \multirow{2}{*}{$\begin{array}{c}\text { PGRs } \\
\left(\mathrm{mg} \cdot \mathrm{dm}^{-3}\right)\end{array}$} & \multicolumn{16}{|c|}{ Treatment number } \\
\hline & 1 & 2 & 3 & 4 & 5 & 6 & 7 & 8 & 9 & 10 & 11 & 12 & 13 & 14 & 15 & 16 \\
\hline 2,4-D & 0.5 & 0.5 & 0.5 & 0.5 & 0.2 & 0.2 & 1 & 1 & 0.5 & 0.5 & 0.5 & 0.5 & 0.5 & 0.5 & 0.2 & 0.2 \\
\hline BA & 0.2 & 0.2 & 0.5 & 0.5 & 0.2 & 0.2 & 0.2 & 0.2 & 0.2 & 0.2 & 0.5 & 0.5 & 0 & 0 & 0 & 0 \\
\hline NAA & 0.5 & 0.5 & 0.5 & 0.5 & 0.5 & 0.5 & 0.5 & 0.5 & 0 & 0 & 0 & 0 & 0 & 0 & 0 & 0 \\
\hline $\mathrm{CH}$ & 0 & 200 & 0 & 200 & 0 & 200 & 0 & 200 & 0 & 200 & 0 & 200 & 0 & 200 & 0 & 200 \\
\hline
\end{tabular}

Table 2. Callus induction response to treatments among different carnation cultivars based on Duncan's multiple range grouping

\begin{tabular}{|c|c|c|c|c|c|c|c|c|c|c|c|}
\hline \multicolumn{12}{|c|}{ Callus induction in different carnation cultivars } \\
\hline $\begin{array}{c}\text { Dependent } \\
\text { variable }\end{array}$ & $\begin{array}{l}\text { Visual } \\
\text { score }\end{array}$ & SS & 'Mariposa' & 'Eskimo' & 'Cameron' & 'Tabasco' & 'Tabor' & 'Noblesse' & 'Liberty' & $\begin{array}{l}\text { 'White } \\
\text { Liberty' }\end{array}$ & $\begin{array}{l}\text { 'Grand } \\
\text { Slam' }\end{array}$ \\
\hline \multirow{4}{*}{$\begin{array}{c}\mathrm{CF} \\
0-100 \%\end{array}$} & excellent & $\geq 86$ & & & & & & $91.67 \%$ & & $90.33 \%$ & \\
\hline & good & $51-85$ & 72.33 & & & $62.25 \%$ & & & & & \\
\hline & medium & $25-50$ & & & & & $38.92 \%$ & & & & $37.72 \%$ \\
\hline & weak & $\leq 25$ & & $18.67 \%$ & $22.73 \%$ & & & & $19.67 \%$ & & \\
\hline \multirow{4}{*}{$\begin{array}{c}\text { DCI } \\
\text { 2-30 day }\end{array}$} & excellent & $\leq 9$ & & 6 & & & 5 & & & & \\
\hline & good & $10-19$ & & & & 14 & & & 14 & & \\
\hline & medium & $20-29$ & 25 & & 21 & & & 21 & & & 21 \\
\hline & weak & $\geq 30$ & & & & & & & & 33 & \\
\hline \multirow{4}{*}{$\begin{array}{c}\text { CGR } \\
\text { score } \\
1-5\end{array}$} & excellent & 5 & & 5 & & & 5 & & & & \\
\hline & good & 4 & & & & 4 & & & 4 & & \\
\hline & medium & 3 & & & 3 & & & & & 3 & 3 \\
\hline & weak & $\leq 2$ & 2 & & & & & 1 & & & \\
\hline \multirow{4}{*}{$\begin{array}{c}\text { CC } \\
\text { score } \\
1-5\end{array}$} & green & 5 & 5 & 5 & 5 & 5 & 5 & & 5 & & \\
\hline & $\begin{array}{l}\text { green- } \\
\text { yellow }\end{array}$ & 4 & 4 & 4 & 4 & 4 & 4 & & & & \\
\hline & white & 3 & & & & & & & & 3 & 3 \\
\hline & brown & $\leq 2$ & & & & & & 1 & & & \\
\hline
\end{tabular}

$\mathrm{CF}$ - callus frequency, DCI - days to callus induction (showing the number of days required for visible callus induction), CGR - callus growth rate scored from 1 for lowest to 5 for highest, $\mathrm{CC}$ - callus color scored from 1 for brown to 5 for green, $\mathrm{SS}$ - statistical score 
Table 3. Effects of different PGR treatments on regeneration frequency for plant regeneration in different carnation cultivars

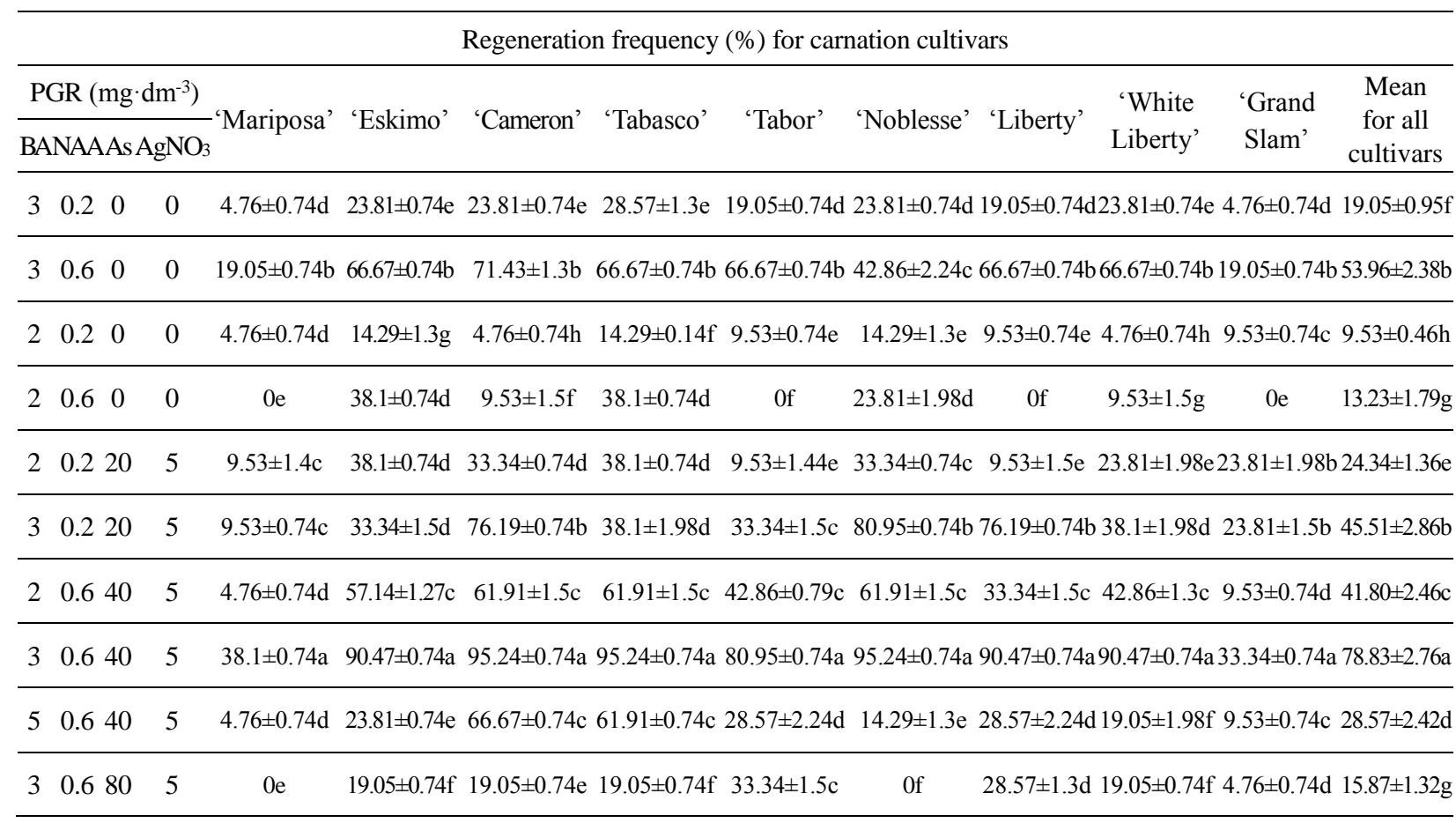

Different letters in a column indicate significant differences according to Duncan's multiple range test $(p<0.05)$; values represent mean $\pm \mathrm{SE}$

Table 4. Effects of different treatments on shoot number per explant for plant regeneration in different carnation cultivars

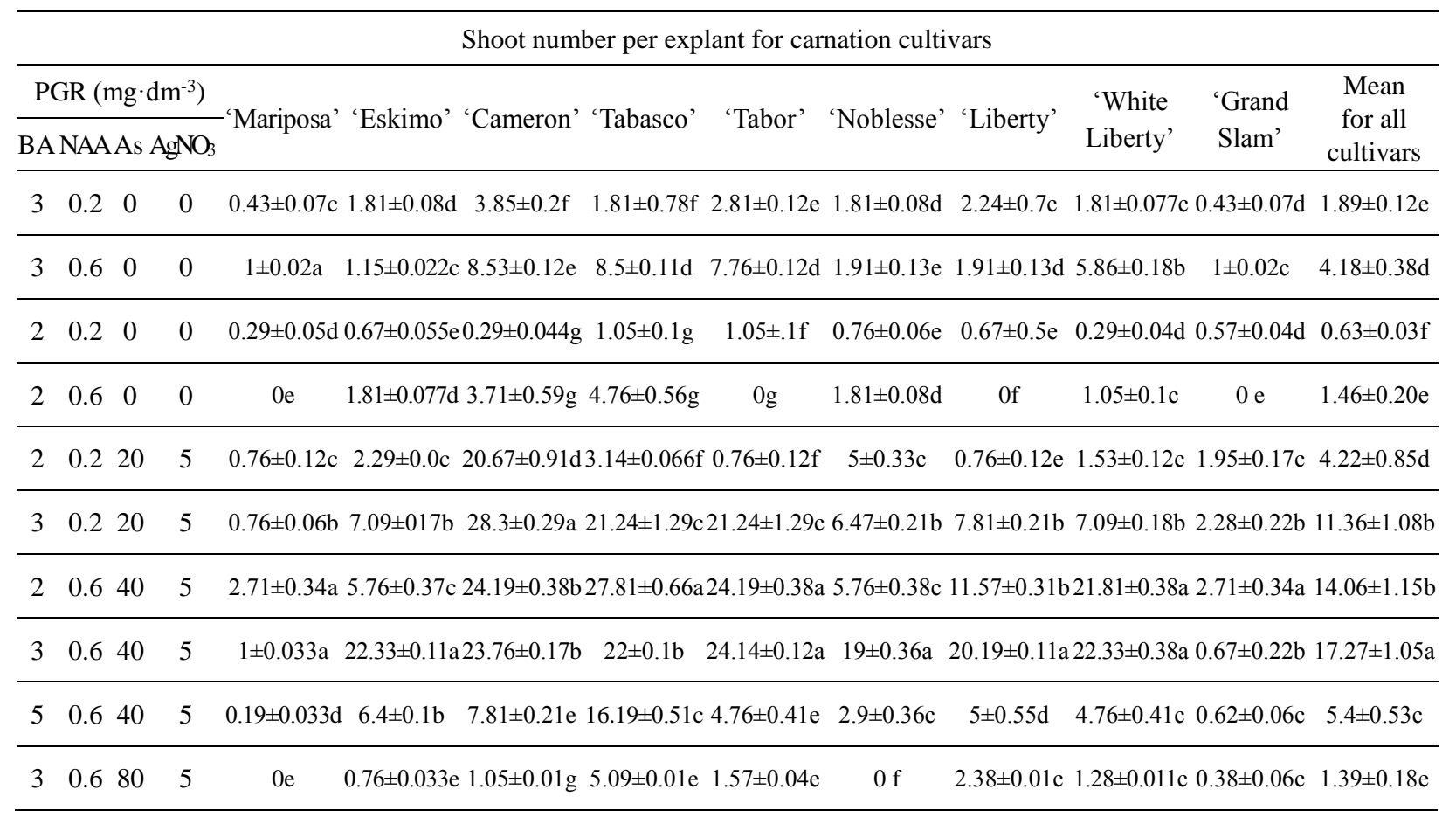

Note: See Table 1 


\section{DISCUSSION}

Because of carnation hybridization breeding barriers (Dyaberi et al. 2015), an efficient protocol for plant organogenesis is important for in vitro mutation breeding and genetic engineering purposes. Direct or indirect shoot regeneration of range of carnation genotypes using different explants has been reported. Taking into account that different carnation cultivars showed different responses to plant regeneration treatments, the optimization of efficient plant regeneration protocol would be valuable (Zia et al. 2020). In the present study, we developed an efficient indirect organogenesis protocol for shoot regeneration for different standard carnation cultivars (Iantcheva 2016). The type and the concentration of PGRs are extremely important in callus induction, and they will subsequently affect the plant regeneration ability (Muhamad et al. 2018). The previous studies showed that a concentration higher than $0.5 \mathrm{mg} \cdot \mathrm{dm}^{-3} 2,4-\mathrm{D}$ resulted to embryogenic calli induction in carnation (Choudhary \& Chin 1995; Karami et al. 2008). In this study, a high rate of organogenesis was observed in the calli induced with a low concentration of 2,4-D. Thakur et al. (2002) also reported efficient organogenic callus induction in carnations using $0.5 \mathrm{mg} \cdot \mathrm{dm}^{-3}$ of $2,4-\mathrm{D}$ and $0.5 \mathrm{mg} \cdot \mathrm{dm}^{-3}$ of NAA. Moreover, for organogenic callus induction from the leaf explant of carnations, the MS medium containing $0.5 \mathrm{mg} \cdot \mathrm{dm}^{-3}$ of $2,4-\mathrm{D}$ and $1 \mathrm{mg} \cdot \mathrm{dm}^{-3}$ of BAP was used. In our experiment the medium supplemented with a low concentration 2,4-D $\left(0.2 \mathrm{mg} \cdot \mathrm{dm}^{-3}\right)$ and $200 \mathrm{mg} \cdot \mathrm{dm}^{-3}$ of $\mathrm{CH}$ showed the highest quality of organogenic calli too.

The MS medium with BAP or without PGRs caused the formation of hyperhydric shoots (Jain et al. 2001). Similarly, in our study, although high concentrations of BAP showed a high regeneration rate, this resulted in the formation of hyperhydric shoots.

The source of the explant is very important for efficient callus induction and, subsequently, for mode of regeneration (Kanwar \& Kumar 2009). For example, carnation petal explants were successfully used for callus induction and somatic embryogenesis (Karami et al. 2008). In most cases leaf explants were used for plant regeneration in carnations (Esmaiel et al. 2013) as the most suitable for plant regeneration in different carnation cultivars (Abu-Qaoud 2013; Esmaiel et al. 2013). Among various types of cytokines and auxins, BA and 2,4-D showed the highest effect on plant regeneration (Yantcheva et al. 1998; Jain et al. 2001; Kantia \& Kothari 2002; Kanwar \& Kumar 2009). Our results showed that a high concentration of auxins (2,4-D or NAA) increased the callus growth rate; however, it had a negative effect on the plant regeneration ability. Using promoters such as silver nitrate, adenine hemisulfate, and casein hydrolysate significantly increased the callus growth rate and the initiation of direct and indirect plant regeneration in different species (Yantcheva et al. 1998; Dubois et al. 2000; Akasaka-Kennedy et al. 2005; Jaberi et al. 2018). In the present study, the above promoters were used as cell division and organogenesis enhancers.

For indirect organogenesis, the possibility of somaclonal variation is an important challenge (Nalousi et al. 2019). Flow cytometry has been confirmed as a rapid, simple, and reproducible technique for the assessment of DNA content and ploidy variation occurring in indirect plant regeneration (Escobedo-Gracia-Medrano et al. 2018). Therefore, in the present study, to evaluate the genetic stability of regenerated plants, flow cytometry was used for genome size estimation compared with donor plants. The results showed that there was a high similarity in terms of ploidy levels between the regenerated and donor plants. Previously, flow cytometry has been used to detect somaclonal variation in Arracacia xanthorrhiza plants regenerated via indirect morphogenesis, and no genomic changes were found (Vitamvas et al. 2019).

\section{CONCLUSION}

Here, an efficient protocol for high-frequency organogenic callus induction from leaf explants and plant regeneration via indirect shoot organogenesis was established using different BA, 2,4-D, $\mathrm{NAA}, \mathrm{AgNO}_{3}, \mathrm{As}$, and $\mathrm{CH}$, in nine standard carnation cultivars. A highest frequency of organogenic callus induction was obtained in medium containing $0.2 \mathrm{mg} \cdot \mathrm{dm}^{-3}$ of $2,4-\mathrm{D}$ and $200 \mathrm{mg} \cdot \mathrm{dm}^{-3}$ of $\mathrm{CH}$. 
In the most of studied cultivars, the highest regeneration rate and shoot number per explant were obtained in the MS medium supplemented with $3 \mathrm{mg} \cdot \mathrm{dm}^{-3}$ of BA, $0.6 \mathrm{mg} \cdot \mathrm{dm}^{-3}$ of NAA, $5 \mathrm{mg} \cdot \mathrm{dm}^{-3}$ of $\mathrm{AgNO}_{3}$, and $40 \mathrm{mg} \cdot \mathrm{dm}^{-3}$ of As. Silver nitrate and adenine hemisulfate showed a significant effect as regeneration promoters. The resulted carnation regenerants proved to be stable against ploidy level, which make the obtained protocol suitable for in vitro breeding programs.

\section{Acknowledgments}

The authors are thankful to the Ornamental Plants Research Center (OPRC) for providing laboratory facilities and financial support.

\section{REFERENCES}

Abu-Qaoud H. 2013. Adventitious shoot formation and plant regeneration from leaf explants of carnation (Dianthus caryophyllus L.). African Journal of Biotechnology 12(21): $3244-3249 . \quad$ DOI: 10.5897/ajb2013.12159.

Akasaka-Kennedy Y., Yoshida H., Takahata Y. 2005. Efficient plant regeneration from leaves of rapeseed (Brassica napus L.): the influence of $\mathrm{AgNO}_{3}$ and genotype. Plant Cell Reports 24(11): 649-654. DOI: 10.1007/s00299-005-0010-8.

Al Ramadan R., Karas M., Ranušová P., Moravčíková J. 2021. Effect of silver nitrate on in vitro regeneration and antioxidant responses of oilseed rape cultivars (Brassica napus L.). Journal of Microbiology, Biotechnology and Food Sciences 10(6); e4494; 4 p. DOI: $10.15414 /$ jmbfs. 4494.

Arora K., Sharma M., Srivastava J., Ranade S.A., Sharma A.K. 2011. In vitro cloning of Azadirachta indica from root explants. Biologia Plantarum 55(1): 164 168. DOI: 10.1007/s10535-011-0023-9.

Azadi P., Bagheri H., Nalousi A.M., Nazari F., Chandler S.F. 2016. Current status and biotechnological advances in genetic engineering of ornamental plants. Biotechnology Advances 34(6): 1073-1090. DOI: 10.1016/j.biotechadv.2016.06.006.

Cardoso J.C. 2019. Silver nitrate enhances in vitro development and quality of shoots of Anthurium andraeanum. Scientia Horticulturae 253: 358-363. DOI: 10.1016/j.scienta.2019.04.054.
Casas J.L., Olmos E., Piqueras A. 2010. In vitro propagation of carnation (Dianthus caryophyllus L.). Methods in Molecular Biology 589: 109-116. DOI: 10.1007/978-1-60327-114-1_11.

Choudhary M.L., Chin C.-K. 1995. Somatic embryogenesis in cell suspension culture of carnation (Dianthus caryophyllus L.). Plant Growth Regulation 16(1): 1-4. DOI: $10.1007 / \mathrm{bf00040500.}$

Dubois L.A.M., de Vries D.P., Koot A. 2000. Direct shoot regeneration in the rose: Genetic variation of cultivars. Gartenbauwissenschaft 65(1): 45-49.

Dyaberi A., Dhananjaya M.V., Kumar R., Rao T.M. 2015. Floral biology and seed setting in standard carnation (Dianthus caryophyllus). Indian Journal of Agricultural Sciences 85(9): 1175-1180.

Escobedo-Gracia-Medrano R.M., Burgos-Tan M.J., KuCauich J.R., Quiroz-Moreno A. 2018. Using flow cytometry analysis in plant tissue culture derived plants. Methods in Molecular Biology 1815: 317 332. DOI: 10.1007/978-1-4939-8594-4_22.

Esmaiel N.M., Al-Doss A.A., Barakat M.N. 2013. An assessment of in vitro culture and plant regeneration from leaf base explants in carnation (Dianthus caryophyllus L.). Journal of Food, Agriculture and Environment 11(1): 1113-1117. DOI: 10.1234/4.2013.4140.

Gatica Arias A.M., Muñoz Valverde J., Ramírez Fonseca P., Valdez Melara M. 2010. In vitro plant regeneration system for common bean (Phaseolus vulgaris): effect of $\mathrm{N}^{6}$-benzylaminopurine and adenine sulphate. Electronic journal of Biotechnology 13(1): 6-7. DOI: 10.2225/vol13-issue1-fulltext-7.

Iantcheva A. 2016. Somatic embryogenesis and genetic transformation of carnation (Dianthus caryophyllus L.). In: Mujib A. (Ed.), Somatic embryogenesis in ornamentals and its applications. India, pp. 107120. DOI: 10.1007/978-81-322-2683-3_7.

Jaberi M., Azadi P., Gharehyazi B, Khosrowchahli M., Sharafi A., Aboofazeli N., Bagheri H. 2018. Silver nitrate and adenine sulphate induced high regeneration frequency in the recalcitrant plant Cosmos bipinnatus using cotyledon explants. Journal of Horticultural Science and Biotechnology 93(2): 204208. DOI: $10.1080 / 14620316.2017 .1358111$.

Jain A., Kantia A., Kothari S.L. 2001. De novo differentiation of shoot buds from leaf-callus of Dianthus caryophyllus $\mathrm{L}$. and control of hyperhydricity. Scientia Horticulturae 87(4): 319-326. DOI: 10.1016/s0304-4238(00)00185-0.

Kantia A., Kothari S.L. 2002. High efficiency adventitious shoot bud formation and plant regeneration from leaf explants of Dianthus chinensis L. Scientia Horticulturae $\quad 96(1-4)$ : 205-212. DOI: 10.1016/s0304-4238(02)00081-x. 
Kanwar J.K., Kumar S. 2009. Influence of growth regulators and explants on shoot regeneration in carnation. Horticultural Science 36(4): 140-146. DOI: 10.17221/1/2009-hortsci.

Karami O., Deljou A., Kordestani G.K. 2008. Secondary somatic embryogenesis of carnation (Dianthus caryophyllus L.). Plant Cell, Tissue and Organ Culture 92(3): 273-280. DOI: 10.1007/s11240-007-9332-2.

Khaleda L., Al-Forkan M. 2006. Stimulatory effects of casein hydrolysate and proline in in vitro callus induction and plant regeneration from five deepwater rice (Oryza sativa L.). Biotechnology 5(3): 379384. DOI: 10.3923/biotech.2006.379.384.

Lakshmi P.V.C., Reddy C.M.N., Rathinapriya P., Ramesh M., Srinivas B. 2021. In-vitro seed germination and effect of TDZ and $\mathrm{AgNO}_{3}$ on high frequency shoot regeneration from Ruellia tuberosa L., using cotyledonary node explants. International Journal of Pharmaceutical Sciences and Research 12(4): $2211-$ 2224. DOI: 10.13040/ijpsr.0975-8232.12(4).2211-24.

Maurya R.L., Kumar M., Malik S., Yadav M.K., Sengar R.S. 2020. Morphological variation and genetic diversity in carnation (Dianthus caryophyllus L.) using agro-morphic traits. International Journal of Agriculture, Environment and Biotechnology 13(3): 299-304. DOI: 10.30954/0974-1712.03.2020.6.

Maurya R.L., Kumar M., Sirohi U., Priya, Chaudhary V., Sharma V.R. et al. 2021. An effective micropropagation protocol and determination of the clonal fidelity of in vitro developed microshoots of carnation (Dianthus caryophyllus L.) using SSR markers Nucleus; 7 p. DOI: 10.1007/s13237-021-00362-3.

Muhamad S.N.S., Ling A.P.-K., Wong C.-L. 2018. Effect of plant growth regulators on direct regeneration and callus induction from Sargassum polycystum C. Agardh. Journal of Applied Phycology 30(6): 3299-3310. DOI: 10.1007/s10811-018-1649-1.

Murashige T., Skoog F. 1962. A revised medium for rapid growth and bio assays with tobacco tissue cultures. Physiologia Plantarum 15: 473-497. DOI: 10.1111/j.1399-3054.1962.tb08052.x.

Nalousi A.M., Hatamzadeh A., Azadi P., Mohsenpour M. Samizadeh Lahiji H. 2019. A procedure for indirect shoot organogenesis of Polianthes tuberosa L. and analysis of genetic stability using ISSR markers in regenerated plants. Scientia Horticulturae 244: 315-321. DOI: 10.1016/j.scienta.2018.09.066.

Ntui V.O., Azadi P., Supaporn H., Mii M. 2010. Plant regeneration from stem segment-derived friable callus of "Fonio" (Digitaria exilis (L.) Stapf.). Scientia Horticulturae 125(3): 494-499. DOI: 10.1016/j.scienta.2010.04.017.

Pandey A., Tamta S. 2014. In vitro propagation of the important tasar oak (Quercus serrata Thunb.) by casein hydrolysate promoted high frequency shoot proliferation. Journal of Sustainable Forestry 33(6): 590-603. DOI: 10.1080/10549811.2014.912587.

Thakur K., Kanwar K. 2018. In vitro plant regeneration by organogenesis from leaf callus of carnation, $\mathrm{Di}$ anthus caryophyllus L. cv. 'Master'. Proceedings of the National Academy of Sciences, India Section B: Biological Sciences 88(3): 1147-1155. DOI: 10.1007/s40011-017-0851-2.

Thakur M., Sharma D.R., Sharma S.K. 2002. In vitro selection and regeneration of carnation (Dianthus caryophyllus L.) plants resistant to culture filtrate of Fusarium oxysporum f.sp. dianthi. Plant Cell Reports 20(9): 825-828. DOI: 10.1007/s00299-001-0412-1.

Thu H.T.M., Naing A.H., Jeong H.Y., Kim C.K. 2020. Regeneration of genetically stable plants from in vitro vitrified leaves of different carnation cultivars. Plants $\quad 9(8) ; \quad 950 ; \quad 12$ p. $\quad$ DOI: $10.3390 /$ plants 9080950 .

Vitamvas J., Viehmannova I., Cepkova P.H., Mrhalova H., Eliasova K. 2019. Assessment of somaclonal variation in indirect morphogenesis-derived plants of Arracacia xanthorrhiza. Pesquisa Agropecuária Brasileira 54; e00301; 9 p. DOI: 10.1590/s1678-3921.pab2019.v54.00301.

Yantcheva A., Vlahova M., Antanassov A. 1998. Direct somatic embryogenesis and plant regeneration of carnation (Dianthus caryophyllus L.). Plant Cell Reports $18(1-2)$ : $148-153 . \quad$ DOI: 10.1007/s002990050548.

Zia M., Yaqoob K., Mannan A., Nisa S., Raza G., ur Rehman R. 2020. Regeneration response of carnation cultivars in response of silver nanoparticles under in vitro conditions. Vegetos 33(1): 11-20. DOI: 10.1007/s42535-019-00074-9. 